\title{
Cutaneous Melanoma Pathologic Primary Tumor TNM Finding v7
}

National Cancer Institute

\section{Source}

National Cancer Institute. Cutaneous Melanoma Pathologic Primary Tumor TNM Finding v7. NCl Thesaurus. Code C88380.

A pathologic finding about one or more characteristics of cutaneous melanoma, following the rules of the TNM AJCC V7 classification system as they pertain to staging of the primary tumor. The TNM pathologic and clinical primary tumor classifications of cutaneous melanoma are the same. (from AJCC 7th Ed.) 